\title{
Ergonomics in the formation of work condition quality
}

\author{
Adam Górny \\ Department of Management Engineering Poznan, University of Technology, 11 Strzelecka St., PL - 60-965 \\ Poznan, Poland
}

\begin{abstract}
The specific organizing the conditions of executing the job makes up the essential decisive about possibility obtainment element of competitive superiority. The ergonomic requirements are essential element of this process. They unite the environment of work with principles of the SCR, causing enlargement the man's part in development of enterprise.
\end{abstract}

Keywords: ergonomics, work condition, environments load, CSR, human factor, human activity

\section{Introduction}

Occupational health and safety is crucial to success of a commercial entity. Part of those considerations is the working environment, which impacts the identified satisfaction level of interested parties. The view about the working environment being an additional element of human needs becomes increasingly obsolete, as it becomes a criterion key to efficient execution of occupational activities and one influencing efficacy and quality of undertaken jobs.

The process of determining working conditions includes requirements, which ought to be recognised as vital to assuring safety at the workplace. Among criteria describing working conditions one can list i.a. [1-3]:

- environmental criteria, related to surrounding's direct impact on health and safety of employees,

- psychological criteria, determining the ability to work,

- criteria determining an employee's performance under changeable conditions of a business environment,

Ergonomic criteria play an important role among the aforementioned. They feature [3]:

- anthropometric requirements, characterising technical equipment in terms of adaptation to dimensions and weight of a human body, or indeed its parts, both in static and dynamic setting, in order to ensure e.g. a rational working position.

- physiological requirements, characterising technical equipments in terms of adaptation to psychological needs, factoring in optimum load on muscles, skeletal, respiratory and cardiovascular systems, joints and limbs,

- psychophysical requirements, related to adapting the workplace to human needs and limitations in order to diminish negative impact of nuisance caused by psychophysical factors,

- hygienic requirements, related to adapting the workplace to human needs and limitations in order to diminish negative impact of environmental factors and to provide comfort in the working environment.

The above-mentioned requirements allow for obtaining an optimum characteristic of a workplace environment, conforming to the WHO's definition of safety. Its fundamental, specified objective is to achieve optimisation of loads, as opposed to a hazard free environment. Such concept meets promoted for many years by ILO [6] approach, contributing to an increasing interest in human, viewed as the subject of work environment, where ergonomics - as a qualitative element of described requirements - is raised to a superior rank, effectively deciding about effectiveness of undertaken actions.

Ergonomic criteria are an essential part of the above requirements. The standard to which they are 
completed, directly influences work comfort and quality $[6,10]$.

\section{Ergonomics requirements - the importants elements of work environments load}

Work environment is described by an array of factors conditioning the intensity of occurring loads, determining employees' ability to perform occupational activities. By developing work environment in a fashion assuring required level of loads optimisation, one should pay attention to its position in the interested parties' satisfaction chain, including employees.

Particularly important is to correctly articulate the requirements. Requirements related to work environment should be determined in a fashion allowing to guarantee reaching required level of safety, satisfying needs and expectations of interested parties, employees but also, indirectly, the remaining company stakeholders. Attention could be drawn here, to the relation between the work environment and conditions, and economic criteria determining the company's market position.

A salient element of those requirements is ergonomic criteria, providing knowledge presenting possibilities of selecting optimum loads at a workplace. Those requirements ever-often become an integral part of workplace development. Equally often, however, they entail employing criteria originally excluded from normative requirements. They require reaching out for developed principles, outlining how to produce rules counteracting all elements of the working environment, in line with social tasks. One should bear in mind during the process of developing requirements, that the human (employee) is a dominant element in ergonomics [3]. Undertaken actions are aimed at balancing out the human-machine system and assuring its operating reliability. It requires including methodological comprehensiveness and using complementary actions concerning:

- human ergonomics: in form of social and medical issues,

- technical ergonomics: in form of technical and economic, and organisational issues.

Their fundamental aim and job is to minimise occurring hazards and nuisance, effectively optimising loads, determined by failure to comply with ergonomic principles. Listed here can be:
- physiological consequences (e.g. musculoskeletal system disorders), caused by unhealthy positions and excessive or repetitive efforts,

- psychophysiological consequences, caused by psychological overload, underload or stress caused by work, supervising and maintaining work equipment in motion, within limits of its intended use.

Occurrence of loads, related to concerned failing to observe suggested ergonomic solutions often leads to accidents and medical conditions of occupational origin. It emphasises the role and significance of ergonomic requirements in creating a pro humanistic working environment. Such approach can be perceived as a developmental concept of employing ergonomic criteria to develope quality workplaces.

\section{Optimum work condition as the basis of CSR}

The current paradigm is for companies to be required to search for development strategies based (identified) on new sources of competitive advantage, which would allow addressing changes in the global environment $[4,5,7,8]$. It comes at an effort, however, a company aware of its needs and skills, will be able to do it. Globalisation can be perceived as a factor, exerting an influence over companies to streamline their operation $[7,8]$. Thus the need to be ever-more competitive might be viewed as a factor fostering improvement of market credibility. It is worth bearing in mind though, that a company's market position relies also on its reputation. In order to secure it, a company has to care about good relationships with its surrounding (e.g. clients, shareholders, society). As a characteristic form of public opinion, they will determine company perception in the market. Collaboration with parties empowered to influence company image should be multi-dimensional, including green issues. The salient aspect of those actions is company commitment, concerning financial and market underpinning of its operation.

Such optimality is achieved through the concept of Social Corporate Responsibility, which is a specific form of self-imposed, corporate obligation to act ethically and undertake sustainable actions for economic development, minding at the same time life quality of employees and their families, local communities and the entire environment [10].

Ergonomic criteria play an important role in those requirements, which are formalised as ergonomic 
norms or norms containing criteria, traditionally associated with ergonomic criteria.

Those characteristics recognise human limitations - a human being viewed as a crucial development factor, determining the ability to satisfy customer needs and expectations. Including the internal customer, which determines the work quality of organisational units or the company as a whole. In order to follow CSR principles, human factor has to be linked to ergonomic conditions of it operation [11]. Characteristics of the human factor define a human's importance in achieving business aims effectively and efficiently. Human factor determines the ability to implement changes, and to effectively manage every business area.

In context of resources, human factor can be viewed as a constituent of organisation's economic value $[9,10]$. First and foremost though, human factor is an important criterion of satisfying customer needs and expectations effectively. It is the human, who determines the operating efficacy of a business system and its constituting companies, ultimately determining its development potential. Under conditions of developing corporate social responsibility, the manner in which human factor is included in company's strategy, affects how effectively and efficiently business aims are met, which involve balancing out economic, social and ecologic aims, which are indicative of increased sense of solidarity and cohesion between interested parties.

\section{Conclusion \\ The man in the formation of work quality condition}

In order to guarantee effectiveness of occupational activities, it is important to provide optimum working conditions for employees. Including building certain criteria of working environment, allowing to satisfy needs and expectations of interested parties.

Those criteria have to factor in conditions required to meet needs, demands and abilities concerning development of the working environment. Ergonomic criteria play an important role here, through their influence on identified requirements, being part of those requirements at the same time. Ergonomic criteria play three important, mutually complementary roles:

- they are source of ergonomic information,

- they initiate the mechanism of associations and analogies, directing evaluator's thoughts at correct solutions from perspective of ergonomics,
- they can indicate the possibility to use standard, practice-proven solutions, which would be ergonomically exemplary.

Ergonomic criteria allow for building potential relations between requirements. In order to ensure their proper (effective) implementation, those requirements have to be featured in technical documentation of the workplace and working environment under development. They also have to ensure optimum load conditions for the person responsible for correctly carried out work. It has to be perceived as an important element, on which achievement of desired work conditions' quality is contingent.

Fundamental considerations determining developed safety strategy, in relation to human as the subject of working environment, can be established through identifying tasks related to its implementation:

1. Human environment is an environment exerting influence over a human and developing specific awareness. Awareness-developing factors can be put into two groups:

- material working environment, creating safety hazards as well as physiological and psychological nuisance,

- social environment conditions, perceived as a system of social needs and free time activities capable of producing psychosocial nuisance.

2. Level of scientific and technical development has an impact on material working conditions and the level of social burden.

3. Impact of hazards and nuisances depends on the individual affected (sensitivity and sensory responsiveness to external stimuli, psychosocial and biological considerations related to the operating environment)

4. As a result of scientific and technical development, and employee behaviours a synergy effect is created, expressed through accident rate. The synergy effect influences - in form of feedback the intensity of loads at a workplace, compelling further development as well as scientific and technical development.

5. Working conditions impact company effectiveness, particularly because competent employees can be considered as a company's greatest asset.

The way they are implemented determines the efficacy of developing quality, ergonomics-related working conditions. 


\section{References}

[1] A. Górny, Ergonomia w kształtowaniu społecznej odpowiedzialności biznesu (Ergonomics in formation of corporate social responsibility), in: Problemy etyczne w organizacji uczącej się, E. Skrzypek, ed., Uniwersytet Marii Curie - Skłodowskiej, Lublin, 2010.

[2] A. Górny, Ergonomic requirements in system management of industrial safety, Foundation of Control and Management Science, 11(2008), 127-137.

[3] A. Górny, The Elements of Work Environment in the Improvement Process of Quality Management System Structure, in: Advances in Human Factors, Ergonomics, and Safety in Manufacturing and Service Industries, W. Karwowski, G. Salvendy, eds., CRC Press, Taylor \& Francis Group, Boca Raton, 2011 , pp. $599-606$.

[4] Communication from the Commission of the European Parliament, the Council and the European Economic and Social Committee. Implementing the partnership for growth and job: Making Europe a pole of excellence on Corporate Social Responsibility, Commission of the European Communities, $\operatorname{COM}(2006), 136$ final, Brussels, 2006, p. 2.
[5] Communication to the spring European Council: Working together for growth and job. A new start for the Lisbon Strategy, Commission of the European Communities, CO92005) 24 final, Brussels 2005.

[6] Guidelines on occupational safety and health management systems (ILO - OSH 2001), International Labor Organization, Geneva, 2001.

[7] ISO 26000:2010, Guidance on social responsibility

[8] ISO and social responsibility, International Organization for Standardization, Geneve, 2010.

[9] T. Luczka, E. Pawlowski, Selected problems of SMEs' development in the conditions of internationalization and globalization, Publishing House of Poznan University of Technology, Poznan, 2010

[10]T. Shelly, Social capital ... the key to inovation, Eureka, 3(2002), p. 36.

[11]W. Klimaszewska, Społeczna odpowiedzialność biznesu a bezpieczeństwo pracy (Corporate Social Responsibility and occupational health and safety of work), Bezpieczeństwo Pracy, 12 (2005), 7-8. 